\title{
. STUDI ANALISIS KEMAMPUAN PENGELOLAAN \\ KECERDASAN INTERPERSONAL DENGAN PRESTASI MAHASISWA PERGURUAN TINGGI KEAGAMAAN NEGERI DI KALIMANTAN BARAT
}

\author{
Lukas Ahen \\ STAKat Negeri Pontianak \\ Email:ahenlukas66@gmail.com
}

\begin{abstract}
This research is done to know the ability of 7th semester students of IAIN Pontianak and STAKatN Pontianak in managing interpersonal intelligence abilities, and the relationship between the ability to manage interpersonal intelligence and academic achievement. The form of this research is a qualitative descriptive study, with the guided free interview method as data collection. The results showed first, the ability to manage interpersonal intelligence of 7th semester students were still low in an effort to achieve academic learning achievement through their active organization on campus. Second, there is a significant negative relationship between the ability to manage interpersonal intelligence with academic achievement. In this case shows the low ability to manage interpersonal intelligence, followed by low academic achievement.
\end{abstract}

Keywords: Interpersonal Intelligence, Academic Achievement

$\boldsymbol{N} \begin{array}{lrr}\text { anusia } & \text { memiliki } & \text { berbagai } \\ \text { potensi } & \text { kehidupan } & \text { yang }\end{array}$

berkembang sejak dalam kandungan sampai lahir di antaranya potensi kecerdasan interpersonal. Kecerdasan interpersonal berkembang dengan baik di usia remaja terutama ketika berada di bangku pendidikan perguruan tinggi. Oleh karena itu, melalui berbagai kegiatan misalnya menjadi BEM (Badan Eksekutif Mahasiswa) atau organisasi yang lainnya di kampus.

Manusia sebagai individu memiliki kecerdasan personal. Kecerdasan ini terkait dengan cara manusia memahami perasaan, suasana hati, keinginan serta temperamen orang lain. Kecerdasan ini dikategorikan sebagai kecerdasan interpersonal, kecerdasan ini terkait dengan kemampuan untuk memahami dan berinteraksi secara efektif dengan orang lain, membedakan dan menanggapi suasana hati dengan tepat, perangai, motivasi dan hasrat orang lain. Kemampuan memahami dan bekerja dengan orang lain. Inilah kecerdasan yang merupakan keterampilan anak untuk berinteraksi dengan orang lain dengan kemampuan 


\section{Bestari: Jurnal Pendidikan dan Kebudayaan}

Volume 1 Nomor 2 Oktober 2020

untuk memahami dan bekerja dengan orang lain (Sri Widayanti Danutami Widijati, 2018: 187-188).

Belajar mengandung dua pokok pengertian yaitu proses dan hasil belajar. Proses belajar di sini dapat dimaknai sebagai suatu kegiatan dan usaha untuk mencapai perubahan tingkah laku, bahwa belajar sebagai proses adalah sesuatu kegiatan yang dilakukan dengan melibatkan jiwa dan raga. Sedangkan perubahan tingkah laku tersebut merupakan hasil belajar dari pengalaman individu dalam interaksi dengan lingkungannya yang menyangkut kognitif, afektif, dan psikomotorik (Sugihartono, dkk., 2007: 23).

Dalam berorganisasi sangat diperlukan kecerdasan interpersonal, dengan demikian mendapat peluang untuk berkembang dengan baik. Kecerdasan interpersonal dan kemampuan mengelolanya akan berdampak pada pencapaian prestasi di berbagai bidang sesuai dengan bakat dan minat yang dimilikinya. Bagaimana kemampuan interpersonal tersebut dikelola atau diaplikasikan dalam pergaulan untuk berprestasi terutama pergaulan berkomunikasi di lingkungan kampus. Mahasiswa dalam kemampuan interpersonal yaitu dengan teman sebaya, dosen, termasuk dosen pembimbing akademik dan dosen pembimbing skripsi.

Di samping itu, kecerdasan interpersonal yang dimiliki oleh setiap mahasiswa tersebut seharusnya memiliki korelasi atau hubungan dengan pencapaian prestasi belajar di kampus. Oleh karena itu kemampuan mengelola kecerdasan interpersonal yang dimiliki tersebut perlu dikembangkan melalui kegiatan-kegiatan kemahasiswaan di kampus. Kegiatan kemahasiswaan termasuk menjadi pengurus Badan Eksekutif Mahasiswa atau organisasi-organisasi kampus yang lain.

Keberhasilan mahasiswa untuk berprestasi tidak terlepas dari adanya motivasi diri untuk berkomunikasi dalam rangka mengelola kecerdasan interpersonal, baik berkomunikasi dalam berorganisasi atau dengan para stake holder yang ada di kampus. Pengelolaan kecerdasan interpersonal tidak terlepas dari bagaimana mahasiswa itu memiliki bakat dan minat untuk berprestasi serta bagaimana bersikap dan berperilaku di lingkungan kampus. 


\section{Bestari: Jurnal Pendidikan dan Kebudayaan}

Volume 1 Nomor 2 Oktober 2020

Dalam uraian tersebut, penelitan

ini ingin mengetahui bagaimana hubungan kemampuan mengelola kecerdasan interpersonal dengan prestasi belajar mahasiswa perguruan tinggi negeri keagamaan di Kalimantan Barat.

\section{METODE PENELITIAN}

Penelitian ini menggunakan metode penelitian kualitatif deksriptif. Menurut Sugiyono (2013: 15), metode penelitian kualitatif adalah metode penelitian yang berlandaskan pada filsafat postpositivisme, digunakan untuk meneliti pada kondisi obyek yang alamiah, dimana peneliti adalah sebagai instrumen kunci, teknik pengumpulan data dengan triangulasi, analisis data bersifat kualitatif, dan hasil penelitian kualitatif lebih menekankan makna daripada generalisasi.

Penelitian ini dilakukan di perguruan tinggi keagamaan negeri Kalimantan Barat yaitu pada Institut Agama Islam Negeri (IAIN) Pontianak dan Sekolah Tinggi Agama Katolik Negeri (STAKatN) Pontianak. Dipilihnya lokasi penelitian ini berdasarkan tuntutan keaslian penelitian yaitu di lokasi kedua perguruan tinggi tersebut belum pernah dilakukan penelitian yang berkenaan dengan studi analisis hubungan antara kemampuan mengelola kecerdasan interpersonal dengan prestasi belajar mahasiswa. Penelitian ini dengan demikian akan bisa dipertanggungjawabkan dari keasliannya.

Subjek penelitian ini adalah anggota Badan Eksekutif Mahasiswa Keguruan IAIN dan STAKat Negeri Pontianak, dengan alasan karena mahasiswa sebagai anggota Badan Eksekutif Mahasiswa telah memiliki kemampuan dalam mengelola kemampuan interpersonal. Alasan lain adalah di mana mahasiswa yang pernah dan sedang menjadi anggota Badan Eksekutif Mahasiswa memiliki pengalaman sosial yang tinggi dan telah stabil dalam berperilaku.

Metode pengumpulan data dalam penelitian ini digunakan metode wawancara bebas terpimpin, untuk mencari informasi-informasi lisan. Pada wawancara bebas terpimpin, pewawancara membawa kerangka pertanyaan untuk disajikan, sementara orang yang diwawancarai bebas memberikan jawaban yang diminta tanpa merasa dipaksa.

Pengertian teknik pengumpulan data menurut Arikunto adalah cara-cara yang dapat digunakan oleh peneliti 


\section{Bestari: Jurnal Pendidikan dan Kebudayaan}

Volume 1 Nomor 2 Oktober 2020

untuk mengumpulkan data, di mana cara tersebut menunjukkan pada sesuatu yang abstrak, tidak dapat diwujudkan dalam benda yang kasat mata, tetapi dapat dipertontonkan penggunaannya (Suharsimi Arikunto, 2012: 134).

Teknik analisis data adalah proses mengolah data yang dihasilkan. Menurut Sugiyono (2008: 244), teknik analisis data adalah proses mengorganisasikan data ke dalam kategori, melaksanakan sintesa, menyusun ke dalam pola, dan membuat kesimpulan sehingga mudah untuk dipahami. Analisis data dilakukan untuk memperoleh gambaran dari hasil penelitian.

Untuk pengumpulan data primer, peneliti menggunakan teknik wawancara (interview). Melalui teknik wawancara, peneliti berusaha untuk mendapatkan keterangan lisan dari informan mahasiswa. Wawancara dilakukan secara semiterstruktur, dibantu oleh pedoman wawancara sebagai alat pengumpul data, namun berbagai pertanyaan yang diajukan tidak dibatasi. Informan dipilih secara purposive. Dalam upaya memperkuat data yang diperoleh, peneliti juga melakukan observasi, baik terlibat (participant observant) maupun tidak terlibat, dan pendokumentasian. Tahapan ini juga dibantu oleh pedoman observasi sebagai alat pengumpul data. Untuk pengumpulan data sekunder, peneliti melakukan kajian literatur (library research) dengan mengumpulkan data dari berbagai buku, artikel, jurnal, majalah, dan koran.

Dalam penelitian ini data diperoleh dari berbagai sumber, dengan menggunakan teknik pengumpulan data yang beragam (triangulasi), dan dilakukan secara terus-menerus hingga data jenuh. Selain itu, pengamatan yang terus-menerus mengakibatkan variasi data menjadi tinggi. Analisis data dilakukan sejak memasuki lapangan, selama di lapangan, dan setelah di lapangan. Sebelum memasuki lapangan, analisis dilakukan terhadap data hasil studi pendahuluan (data sekunder) yang akan digunakan untuk menentukan fokus penelitian.

Meskipun demikian, fokus dalam penelitian kualitatif masih bersifat sementara dan akan berkembang setelah peneliti berada di lapangan (Sugiyono, 2005). Analisis lapangan dilakukan saat berlangsungnya pengumpulan data, dan setelah selesai pengumpulan data dalam periode tertentu. Pada saat wawancara, peneliti sudah harus melakukan analisis 


\section{Bestari: Jurnal Pendidikan dan Kebudayaan \\ Volume 1 Nomor 2 Oktober 2020}

terhadap jawaban informan yang diwawancarai. Bila setelah dianalisis jawaban informan belum memuaskan, peneliti akan mengajukan pertanyaan lagi hingga pada tahap tertentu diperoleh data yang kredibel.

Penganalisisan dilakukan secara interaktif dan berlangsung terus-menerus hingga data jenuh. Aktivitas dalam analisis data meliputi reduksi data (data reduction), penyajian data (data display), dan penyimpulan (conclusion).

\section{HASIL DAN PEMBAHASAN}

Persepsi merupakan salah satu aspek psikologis yang penting bagimanusia dalam merespon kehadiran berbagai aspek dan gejala di sekitarnya.Persepsi mengandung pengertian yang sangat luas, menyangkut intern danekstern. Berbagai ahli telah memberikan definisi yang beragam tentangpersepsi, walaupun pada prinsipnya mengandung makna yang sama. Menurut Slameto (2010:102) pengertian persepsi adalah proses yang berkaitan dengan masuknya pesan atau informasi ke dalam otak manusia, melalui persepsi manusia terus menerus mengadakan hubungan dengan lingkungannya. Hubungan ini dilakukan lewat inderanya, yaitu indera pengelihat, pendengar, peraba, perasa, dan pencium.

Menurut Kamus Besar Bahasa Indonesia, persepsi adalah tanggapan (penerimaan)langsung dari sesuatu. Proses seseorang mengetahui beberapa hal melaluipanca inderanya. Persepsi individu mengenai diri sendiri; seseorang termotivasi atau tidak untuk melakukan sesuatu banyak tergantung pada proses kognitif berupa persepsi. Persepsi seseorang tentang dirinya sendiri akan mendorong dan mengarahkan perilaku seseorang untuk bertindak. Harga diri dan prestasi; faktor ini mendorong atau mengarahkan individu (memotivasi) untuk berusaha agar menjadi pribadi yang mandiri, kuat, dan memperoleh kebebasan serta mendapatkan status tertentu dalam lingkungan masyarakat, serta dapat mendorong individu untuk berprestasi. Harapan; adanya harapan-harapan akan masa depan. Harapan ini merupakan informasi objektif dari lingkungan yang mempengaruhi sikap dan perasaan subjektif seseorang. Harapan merupakan tujuan dari perilaku. Kebutuhan; manusia dimotivasi oleh kebutuhan untuk menjadikan dirinya sendiri yang berfungsi secara penuh, 


\section{Bestari: Jurnal Pendidikan dan Kebudayaan}

Volume 1 Nomor 2 Oktober 2020

sehingga mampu meraih potensinya secara total. Kebutuhan akan mendorong dan mengarahkan seseorang untuk mencari atau menghindari, mengarahkan dan memberi respon terhadap tekanan yang dialaminya. Kepuasan kerja; lebih merupakan suatu dorongan efektif yang muncul dalam diri individu untuk mencapai goal atau tujuan yang diinginkan dari suatu perilaku.

Jenis dan sifat pekerjaan; dorongan untuk bekerja pada jenis dan sifat pekerjaan tertentu sesuai dengan objek pekerjaan yang tersedia akan mengarahkan individu untuk menentukan sikap atau pilihan pekerjaan yang akan ditekuni. Kondisi ini juga dapat dipengaruhi oleh sejauh mana nilai imbalan yang dimiliki oleh objek pekerjaan yang dimaksud. Kelompok kerja di mana individu bergabung; kelompok kerja atau organisasi tempat di mana individu bergabung dapat mendorong atau mengarahkan perilaku individu dalam mencapai suatu tujuan perilaku tertentu. Peranan kelompok atau organisasi ini dapat membantu individu mendapatkan kebutuhan akan nilai-nilai kebenaran, kejujuran, kebajikan, serta dapat memberikan arti bagi individu sehubungan dengan kiprahnya dalam kehidupan sosial.

Situasi lingkungan pada umumnya; setiap individu terdorong untuk berhubungan dengan rasa mampunya dalam melakukan interaksi secara efektif dengan lingkungannya. Sistem imbalan yang diterima; imbalan merupakan karakteristik atau kualitas dari objek pemuas yang dibutuhkan oleh seseorang yang dapat mempengaruhi motivasi atau dapat mengubah arah tingkah laku dari satu objek ke objek lain yang mempunyai nilai imbalan yang lebih besar.

Sistem pemberian imbalan dapat mendorong individu untuk berperilaku dalam mencapai tujuan. Perilaku dipandang sebagai tujuan, sehingga ketika tujuan tercapai maka akan timbul imbalan. Sumber lain mengungkapkan, bahwa di dalam motivasi itu terdapat suatu rangkaian interaksi antar berbagai faktor. Berbagai faktor yang dimaksud meliputi individu dengan segala unsur-unsurnya: kemampuan dan keterampilan, kebiasaan, sikap dan sistem nilai yang dianut, pengalaman traumatis, latar belakang kehidupan sosial budaya, tingkat kedewasaan, dan sebagainya. Situasi di mana individu bekerja akan menimbulkan berbagai 


\section{Bestari: Jurnal Pendidikan dan Kebudayaan}

Volume 1 Nomor 2 Oktober 2020

rangsangan: persepsi individu terhadap kerja, harapan dan cita-cita dalam kerja itu sendiri, persepsi bagaimana kecakapannya terhadap kerja, kemungkinan timbulnya perasaan cemas, perasaan bahagia yang disebabkan oleh pekerjaan. Proses penyesuaian yang harus dilakukan oleh masing-masing individu terhadap pelaksanaan pekerjaannya. Pengaruh yang datang dari berbagai pihak: pengaruh dari sesama rekan, kehidupan kelompok maupun tuntutan atau keinginan kepentingan keluarga, pengaruh dari berbagai hubungan di luar pekerjaan, reaksi yang timbul terhadap pengaruh individu, perilaku atas perbuatan yang ditampilkan oleh individu, timbulnya persepsi dan bangkitnya kebutuhan baru, cita-cita, dan tujuan.

Dari hasil wawancara dan observasi masih ditemukan $30 \%$ tidak memahami tentang jurusan dan prodi yang baru ditempuh, kemudian responden tidak bisa leluasa dalam memilih prodi, terutama mahasiswa Sekolah Tinggi Agama Katolik (STAKatN) yang baru memiliki satu prodi, sehingga mahasiswa terbatasi dalam penyaluran bakat, minat, serta kurang termotivasi, yang kemudian akan menimbukan sikap dan perilaku dalam pencapaian prestasi belajar akademik. Hal ini menunjukkan rendahnya prestasi belajar akademik bukan hanya dipengaruhi oleh rendahnya kemampuan mengelola kecerdasan interpersonal. Responden sebagian tidak mengenal pengurus inti dan anggota pengurus organisasi kampus di mana mereka menjadi satu di antara pengurusnya. Hal ini menunjukkan bahwa belum optimalnya kecerdasan interpersonal yang dimiliki diaplikasikan dalam berkomunikasi antar pengurus, sehingga hal ini akan berpengaruh pada lambannya pengalaman berorganisasi, saling mengisi tentang belajar untuk berprestasi. Pencapaian IPK tertinggi atau tinggi sebagian besar responden berada di semester 5 ke bawah, bahkan ada IPK tertinggi di semester 2 dan 3. Responden menjadi anggota organisasi kampus ketika rata-rata berada di semester 3 ke atas, hal ini menunjukkan bahwa menjadi pengurus organisasi kampus tidak selalu menjadikan pencapaian prestasi belajar akademik menjadi tinggi. Prestasi belajar adalah hasil yang dicapai oleh seseorang setelah ia melakukan perubahan belajar, baik di sekolah maupun di luar sekolah. 


\section{Bestari: Jurnal Pendidikan dan Kebudayaan}

Volume 1 Nomor 2 Oktober 2020

Di dalam Webster's New International Dictionary mengungkapkan tentang prestasi yaitu: "Achievement test a standardised test for measuring the skill or knowledge by person in one more lines of work a study" (Webster's New International Dictionary, 1951: 20).

Terkait prestasi belajar, Abu Ahmadi dan Widodo Supiyono (2013: 150) berpendapat bahwa secara teori bila suatu kegiatan dapat memuaskan suatu kebutuhan, maka ada kecenderungan besar untuk mengulanginya. Sumber penguat belajar dapat secara ekstrinsik (nilai, pengakuan, penghargaan) dan dapat secara intrinsik (kegairahan untuk menyelidiki, mengartikan situasi). Di samping itu, siswa memerlukan dan harus menerima umpan balik secara langsung. Derajat sukses dari pelaksanaan tugas dapat diukur melalui nilai raport atau nilai tes.

Definisi di atas dapat disimpulkan bahwa pengertian prestasi belajar ialah hasil usaha bekerja atau belajar yang menunjukkan ukuran kecakapan yang dicapai dalam bentuk nilai. Hasil usaha belajar itu berupa nilai-nilai sebagai ukuran kecakapan dari usaha belajar yang telah dicapai seseorang, prestasi belajar ditunjukkan dengan jumlah nilai raport atau tes nilai sumatif. Ada beberapa cara untuk meningkatkan prestasi, satu diantaranya adalah dengan memperhatikan dan mencermati gaya belajar dan cara belajar yang baik.

Responden dalam berorganisasi berkesempatan besar untuk saling berkomunikasi dan saling mengisi, serta memiliki keberanian dan kemampuan berkomunikasi dengan siapapun dalam upaya membantu pencapaian prestasi belajar, akan tetapi kenyataan hasil wawancara di lapangan menunjukkan mereka kurang berkomunikasi termasuk misalnya dengan para dosen. Hal ini menunjukkan bahwa mereka tidak bisa mengelola kecerdasan interpersonal dalam kapasitasnya sebagai pengurus organisasi di kampus. Mind management, kemampuan untuk mengelola dan manage cara berpikir dan pemetaan pengetahuan dalam pikiran, dan memberdayakan secara optimal kemampuan berpikir. Hal ini sangat berkaitan dengan kemampuan intelektual (otak kiri dan otak kanan). Kendatipun talent atau kemampuan otak berbeda-beda, namun seharusnya semua orang harus bisa memetakan dan belajar untuk mengoptimalkan kemampuan diri dalam berpikir dan mengelola cara berpikir dengan baik. 


\section{Bestari: Jurnal Pendidikan dan Kebudayaan \\ Volume 1 Nomor 2 Oktober 2020}

Emotional management, kemampuan untuk mengelola emosi. Kecerdasan emosi sangat dibutuhkan dalam kehidupan manusia ketika berkomunikasi, bekerja, mengambil keputusan, dan dalam berbagai aspek kehidupan. Kematangan emosi harus dimiliki seseorang bila ingin berhasil dalam berbagai aspek kehidupan. Pengendalian diri dan manajemen emosi harus dibangun sebaik mungkin agar manusia memiliki kematangan pribadi.

Sikap sering mencerminkan pribadi seseorang, ini disebabkan karena sikap tidak pernah terpisah dari pribadi yang mendukungnya. Slameto (2003: 188) mengungkapkan bahwa sikap merupakan sesuatu yang dipelajari, dan sikap menentukan bagaimana individu bereaksi terhadap situasi serta menentukan apa yang dicari individu dalam kehidupan.

Oleh karena itu dengan melihat sikap-sikap pada obyek-obyek tertentu, sedikit banyak orang bisa mengetahui pribadi. Apabila kita akan mengubah sikap seseorang, kita harus mengetahui keadaan yang sesungguhnya dari sikap orang tersebut. Dengan mengetahui keadaan sikap itu, kita akan mengetahui pula, mungkin tidaknya sikap tersebut diubah dan bagaimana cara mengubah sikap-sikap tersebut.

Rata-rata responden menyukai dosen, hanya sebagian kecil saja yang menyatakan ada beberapa dosen yang tidak mereka sukai. Hal ini menunjukkan bahwa ada hubungan yang berpotensi untuk dapat berkomunikasi dengan baik yang mengarah pada pencapaian prestasi belajar, namun mereka tidak menggunakan potensi ini. Hanya sebagian kecil dari responden yang tidak menyukai kawannya dalam satu kampus. Hal ini menunjukkan bahwa mereka sudah menghayati akan cinta kasih sesuai dengan ajaran agama. Pada kondisi seperti ini seharusnya juga berpengaruh dalam berkomunikasi untuk pencapaian prestasi belajar. Di sisi lain ada kelemahan dari responden bahwa kemampuan pengelolaan interpersonal kurang mereka lakukan untuk berkomunikasi dengan para dosen baik itu dosen biasa, dosen PA, maupun dosen pembimbing skripsi. Hal ini dapat disimpulkan dari jawaban responden menyatakan mereka jarang bertemu dosen PA dan dosen pembimbing, termasuk dosen lainnya.

Sebagian besar responden bersedia menjadi pengurus organisasi 


\section{Bestari: Jurnal Pendidikan dan Kebudayaan}

Volume 1 Nomor 2 Oktober 2020

kampus hanya sekedar untuk mencari pengalaman dan berproses melalui berorganisasi $(60 \%)$, bekerja untuk kemajuan kampus (20\%), dan sisanya hanya sekedar menyibukkan diri. Hal ini menunjukkan bahwa mereka tidak menghubungkan diri dengan prestasi belajar. Walaupun diketahui bersama bahwa mahasiswa yang terpilih menjadi organisasi kampus rata-rata memiliki kecerdasan. Waktu luang (sebelum acara dimulai, istirahat, dll.) yang tersedia pada acara pertemuan atau rapat organisasi kampus dari 30 responden tidak ada yang berdiskusi tentang proses pembelajaran atau kegiatan belajar, 53\% berbicara tentang program kerja organisasi kampus dan berikut organisasi kampus, $6 \%$ berbicara tentang pengembangan diri dan keagamaan, $20 \%$ berbicara tentang kemajuan dan persoalan kampus, kemudian yang 20\% lainnya tidak menyatakan pendapat. Hal ini menunjukkan bahwa mahasiswa yang ikut dalam organisasi kampus tidak menghubungkan dirinya dengan proses belajar mengajar, sehingga otomatis tidak berpengaruh terharap prestasi belajar dan kecerdasan pengelolaan kecerdasan interpersonal. Di sisi lain justru diharapkan dalam berorganisasi di kampus berjalan komunikasi interpersonal dalam menuju ke prestasi belajar.

Aktivitas adalah segala kegiatan yang dilaksanakan baik secara jasmani atau rohani. Aktivitas mahasiswa selama proses belajar mengajar merupakan salah satu indicator adanya keinginan siswa untuk belajar. Aktivitas ini merupakan kegiatan atau perilaku yang terjadi selama proses belajar mengajar. Kegiatan- kegiatan yang dimaksud adalah kegiatan yang mengarah pada proses belajar seperti bertanya, mengajukan pendapat, mengerjakan tugas-tugas, dapat menjawab pertanyaan guru dan bias bekerjasama dengan siswa lain, serta tanggung jawab terhadap tugas yang diberikan. Berdasarkan hasil wawancara, keaktifan masing-masing responden dalam keikutsertaan dalam setiap kegiatan organisasi kampus sebagian besar (90\%) aktif, hanya $10 \%$ yang tidak aktif. Hal ini menunjukkan bahwa organisasi kampus cukup hidup dan menarik. Hanya perlu pembinaan dari segi bagaimana kegiatan organisasi kampus berdampak positif terhadap pencapaian prestasi belajar. Motivasi dalam berorganisasi kampus $60 \%$ untuk mendapatkan pengalaman, menambah 


\section{Bestari: Jurnal Pendidikan dan Kebudayaan \\ Volume 1 Nomor 2 Oktober 2020}

wawasan, bekal masa depan untuk berorganisasi, $20 \%$ tidak bisa olah, dan 20\% tidak berpendapat. Silalahi (2002: 341) mengatakan bahwa motivasi juga didefinisikan sebagai dorongan dari dalam diri individu berdasarkan mana dari berperilaku dengan cara tertentu untuk memenuhi keinginan dan kebutuhannya. Adapun permotivasian dapat diartikan sebagai pemberian motif-motif sebagai pendorong agar orang bertindak, berusaha untuk mencapai tujuan organisasional.Hal ini mungkin disebabkan oleh dampak terhadap dirinya tentang prestasi belajar kurang. Namun di sisi lain, jawaban responden menyatakan bahwa ikut berorganisasi kampus berharap termotivasi untuk belajar selesai tepat waktu bukan dari segi prestasi $(90 \%)$ dan $6 \%$ tidak berharap untuk termotivasi. Minat belajar responden di semester 5 ke bawah cukup tinggi (70\%), hanya 7 responden yang rendah, dan 2 responden tidak menyatakan pendapat. Hal ini sesuai dengan pembahasan terdahulu bahwa pencapaian IPK tertinggi sebagian pada semester 2 dan 3, dan pada semester 4, 5 , dan seterusnya menurun, walau tidak semuanya demikian. Di samping itu menunjukkan bahwa minat belajar dari semester ke semester juga menurun.

\section{SIMPULAN}

Berdasarkan hasil analisis data kualitatif dari hasil observasi dan wawancara ditemukan 28 temuan penelitian. Mahasiswa semester $7 \mathrm{ke}$ bawah, dari hasil pembahasan dan data hasil analisis, menunjukkan bahwa kemampuan mengelola kecerdasan interpersonalnya masih rendah dalam upaya mencapai prestasi belajar akademik melalui keaktifannya berorganisasi di kampus. Pada mahasiswa semester 7 ke bawah terdapat hubungan yang signifikan negatif antara kemampuan mengelola kecerdasan interpersonal dengan prestasi akademik. Mahasiswa semester 7 ke bawah yang tergabung dalam organisasi kampus, dalam hal ini menunjukkan rendahnya kemampuan mengelola kecerdasan interpersonal, diikuti pula dengan rendahnya prestasi akademik.

\section{DAFTAR PUSTAKA}

Ahmadi, A. dan Supriyono, W. 2013. Psikologi Belajar. Bandung: Rineka Cipta.

Arikunto, S. 2011. Metodologi Penelitian. Jakarta: PT. Rineka Cipta. 


\section{Bestari: Jurnal Pendidikan dan Kebudayaan}

Volume 1 Nomor 2 Oktober 2020

Arikunto, S. 2012. Prosedur Penelitian

Suatu Pendekatan Praktek.

Jakarta: PT. Rineka Cipta.

Hamdes. 2014. Napak Tilas STAIN

Pontianak ke IAIN Pontianak:

Harapan Masyarakat Kalbar

Terwujud. Pontianak: IAIN

Pontianak Press.

Moleong, L. J. 2013. Metodologi

Penelitian Kualitatif. Bandung:

PT. Remaja Rosdakarya.

Muchrotien, A. 2011. Modul Psikologi

Perkembangan. Jakarta:

Direktoran Jenderal Bimbingan

Masyarakat Katolik Kementerian

Agama Republik Indonesia.

Muhni, Djuretna A. Imam. 1994. Moral

dan Religi Menurut Emile

Durkheim dan Henri Bergson.

Yogyakarta: Kanisius.

Purwanto, M. N.. 2010. Psikologi

Pendidikan. Bandung: Remaja Karya.

Riduwan. 2004. Metode Riset. Jakarta:

Rineka Cipta

Silalahi, U. 2002. Pemahaman Praktis

Asas-asas Manajemen. Bandung:

CV. Mandar Maju.

Slameto. 2010. Belajar dan

Faktor-faktor yang

Mempengaruhinya. Jakarta: PT.

Rineka Cipta.
Sutopo, H. B. 2006. Metodologi Penelitian Kualitatif. Surakarta: Universitas Sebelas Maret

Sugihartono, dkk. Psikologi Pendidikan. Yogyakarta: UNY Press.

Sugiyono. 2005. Memahami Penelitian Kualitatif. Bandung: $\mathrm{CV}$. Alfabeta.

Sugiyono. 2008. Memahami Penelitian Kualitatif. Bandung: CV. Alfabeta.

Sugiyono. 2013. Memahami Penelitian Kualitatif. Bandung: CV. Alfabeta. . 2012. Metode Penelitian Pendidikan Pendekatan Kuantitatif, Kualitatif, dan $R \& D$. Bandung: CV. Alfabeta.

Widayanti, S. dan Widijati, U. 2008. Mengoptimalkan 9 Zona Kecerdasan Majemuk Anak. Yogyakarta: Luna Publisher. 